\title{
Bioclimatic envelope model of climate change impacts on blanket peatland distribution in Great Britain
}

\author{
Angela V. Gallego-Sala ${ }^{1,10, *}$, Joanna M. Clark ${ }^{2,3,11}$, Joanna I. House ${ }^{1}$, Harriet G. Orr ${ }^{4}$, \\ I. Colin Prentice ${ }^{1,5,6}$, Pete Smith ${ }^{7}$, Timothy Farewell ${ }^{8}$, Stephen J. Chapman ${ }^{9}$ \\ ${ }^{1}$ QUEST, Department of Earth Sciences, University of Bristol, Wills Memorial Building, Queens Road, Bristol BS8 1RJ, UK \\ ${ }^{2}$ Wolfson Carbon Capture Laboratory, School of Biological Sciences, Bangor University, Deiniol Road, Bangor, \\ Gwynedd LL57 2UW, UK \\ ${ }^{3}$ Grantham Institute for Climate Change Fellow, Civil and Environmental Engineering, Imperial College London, \\ Skempton Building, South Kensington, London SW7 2AZ, UK \\ ${ }^{4}$ Research and Innovation (Climate Change), Environment Agency, Environment Centre Wales, Deiniol Road, \\ Bangor LL57 2UW, UK \\ ${ }^{5}$ Division of Biology, Macquarie University, North Ryde, NSW 2109, Australia \\ ${ }^{6}$ Grantham Institute for Climate Change, Division of Life Sciences, Imperial College London, Silwood Park, Ascot, \\ Berkshire SL5 7PY, UK \\ ${ }^{7}$ Institute of Biological and Environmental Science, School of Biological Sciences, University of Aberdeen, \\ Cruickshank Building, 23 St. Machar Drive, Aberdeen AB24 3UU, UK \\ ${ }^{8}$ National Soil Resources Institute, Cranfield University, Cranfield, Bedfordshire MK43 0AL, UK \\ ${ }^{9}$ Macaulay Land Use Research Institute, Craigiebuckler, Aberdeen AB15 8QH, UK \\ ${ }^{10}$ Present address: Department of Earth and Ecosystem Sciences, Division of Physical Geography and Ecosystems Analysis, \\ Lund University, Sölvegatan 12, 22362 Lund, Sweden \\ ${ }^{11}$ Present address: Walker Institute for Climate Systems Research and Soils Research Centre, Geography and Environmental \\ Science, School of Human and Environmental Sciences, University of Reading, Whiteknights, Reading RG6 6DW, UK
}

\begin{abstract}
Blanket peatlands are rain-fed mires that cover the landscape almost regardless of topography. The geographical extent of this type of peatland is highly sensitive to climate. We applied a global process-based bioclimatic envelope model, PeatStash, to predict the distribution of British blanket peatlands. The model captures the present areal extent (Kappa $=0.77$ ) and is highly sensitive to both temperature and precipitation changes. When the model is run using the UKCIP02 climate projections for the time periods 2011-2040, 2041-2070 and 2071-2100, the geographical distribution of blanket peatlands gradually retreats towards the north and the west. In the UKCIP02 high emissions scenario for 2071-2100, the blanket peatland bioclimatic space is $\sim 84 \%$ smaller than contemporary conditions (1961-1990); only parts of the west of Scotland remain inside this space. Increasing summer temperature is the main driver of the projected changes in areal extent. Simulations using 7 climate model outputs resulted in generally similar patterns of declining aereal extent of the bioclimatic space, although differing in degree. The results presented in this study should be viewed as a first step towards understanding the trends likely to affect the blanket peatland distribution in Great Britain. The eventual fate of existing blanket peatlands left outside their bioclimatic space remains uncertain.
\end{abstract}

KEY WORDS: Bioclimatic envelope $\cdot$ Model $\cdot$ Blanket peatlands $\cdot$ Peat $\cdot$ Climate change $\cdot$ Great Britain - Resale or republication not permitted without written consent of the publisher

\section{INTRODUCTION}

Blanket peatlands are ombrotrophic mires that cover the landscape, developing on ground sloping as steeply as 25 degrees or even steeper, albeit only on small patches (Moore \& Bellamy 1973, Moore 2002, BRIG 2008, S. J. Chapman pers. obs.). Since they occur in regions of extremely oceanic climate, they constitute a rare ecosystem type at the global scale, found only in the maritime fringes of the continental masses, e.g. in 
Iceland, Ireland, western Britain, coastal Fennoscandia, Kamchatka, the Falkland Islands, Patagonia, Tasmania, New Zealand, Nova Scotia, the Pacific coast of Alaska and Newfoundland (Lindsay et al. 1988, Wieder \& Vitt 2006). Blanket peatlands in Great Britain are important not only because they are examples of a globally rare ecosystem type, but because they provide a wealth of ecosystem services-e.g. livestock production, carbon storage, water regulation and natural hazard regulation (floods, wildfires) - and recreational and aesthetic benefits, as well as act as archives of the past (Cornell 2010, this Special, Maltby 2010, this Special). British blanket peatlands also support significant biodiversity, including an abundant representation of species that are rare at a global scale, such as the higher plants Scirpus cespitosus, Erica tetralix and Eriophorum vaginatum and the macroinvertebrates Rhithrogena mayflies, luctrid stoneflies, limnephilid caddisflies and elminthid coleoptera (Pearce-Higgins et al. 2009, Ramchunder et al. 2009).

Bioclimatic envelope modelling, also referred to as ecological niche modelling, is widely used to study the current distribution of species and to project potential changes under future climate scenarios (e.g. Sykes et al. 1996, Berry et al. 2002, Tuck et al. 2006, Huntley et al. 2007). In this type of model, a bioclimatic envelope (or space) is characterized by climatic tolerance limits (thresholds) expressed in terms of one or (usually) several climate variables. Statistical envelope models, which now exist in many variants, statistically correlate the current species spatial distribution with climate variables. These models can be contrasted with processbased envelope models in which limit values are fitted for selected bioclimatic variables chosen because of their relation to known or hypothesized physiological causes of the distributional limits (Pearson \& Dawson 2003). The model presented in this study falls into the latter category. Both statistical and process-based bioclimatic envelope models can, in principle, be applied to ecosystems (habitats) as well as species. Peatland ecosystems exist within well-defined climatic thresholds (Wieder \& Vitt 2006) and their observed distributions are therefore amenable to description using a bioclimatic envelope model. Regional distributions of peatlands have already successfully been mapped in Canada (Gignac et al. 2000) and Fennoscandia (Parviainen \& Luoto 2007) using various statistical bioclimatic envelope models.

The limitations of bioclimatic envelope models for species distribution have been extensively described and mainly stem from disregarding factors such as biotic interactions, evolutionary change or dispersal ability; it has been suggested that dynamic vegetation models are better equipped to predict changes in species distribution (Woodward \& Beerling 1997, Davis et al. 1998, Pearson \& Dawson 2003). However, bioclimatic envelope models can still provide a first approximation to the fate of species or habitats in a changed climate and may be able to highlight ecosystems at risk under a changed climate. As such, they are easily applicable tools suitable to inform policy and environmental management (Pearson \& Dawson 2003, Heikkinen et al. 2006).

Direct human impacts (e.g. fires, peat extraction for energy purposes and horticulture, and drainage) and indirect impacts through climate change pose a threat to British blanket peatlands (Moore 2002). Owing to the now widely accepted significance of these ecosystems, a number of studies have been undertaken to ascertain how these various processes will shape the future of British peatlands (e.g. Barkham 1993, Bragg \& Tallis 2001, Dawson et al. 2003, Davies et al. 2008, Bonn et al. 2009, Reed et al. 2009). The present study contributes to continuing investigations into the fate of British peatland ecosystems by applying a simple but globally applicable and process-based bioclimatic envelope model using present and projected future climates. We use UKCIP02 future climate projections at a fine scale $(5 \times 5 \mathrm{~km}$ grid cells $)$ to investigate changes in the areal extent of the blanket peatland envelope. These climate projections are downscaled from the HadCM3 global climate model, GCM (Met Office Hadley Centre, UK). Additionally, we examine future projections of the geographical distribution of blanket peatland bioclimatic space based on 7 GCM outputs at a coarser scale $\left(0.5^{\circ} \times 0.5^{\circ}\right.$ grid cells $)$ to place the results obtained with UKCIP02 projections into a wider context of climate model uncertainty.

Clark et al. (2010, this Special) have applied a suite of statistical bioclimatic envelope models calibrated using climatic conditions and present-day blanket peatland extent in Great Britain to simulate future distributions of blanket peatland bioclimatic envelope. Application of a globally calibrated model to Great Britain provides an independent comparison of the performance and future projections of the statistical models calibrated on data from Great Britain alone.

\section{METHODOLOGY}

\subsection{PeatStash}

A simple process-based bioclimatic model (STASH), originally used to estimate the present distribution of boreal and temperate forest trees in Europe (Sykes et al. 1996), was adapted to delimit the potential distribution of different types of peatland ecosystems globally, including aapa, palsa, blanket and raised mires (A. V. Gallego-Sala, J. Clark, J. House, I. C. Prentice and others unpubl.). The resulting model (PeatStash) was 
then applied to predict the distribution of blanket peatlands within Great Britain.

PeatStash calculates bioclimatic variables from longterm mean monthly values of temperature, precipitation and the fraction of possible sunshine hours (a measure inversely related to cloud cover). For blanket peatlands, the bioclimatic variables employed are mean annual temperature, mean temperature of the warmest month and a moisture index, on a grid-cell basis. The moisture index (MI) is calculated following the definition given by the United Nations Environment Programme (1992):

$$
\mathrm{MI}=P / \mathrm{PET}
$$

where $P$ is the mean annual precipitation ( $\mathrm{mm}$ ) and PET is the mean annual potential evapotranspiration ( $\mathrm{mm}$ ). However, because there are various non-equivalent definitions of PET, we substitute an estimate of the equilibrium evapotranspiration (EET), which is a function of net radiation and temperature only. For empirical relationships among different moisture indices, including MI as calculated here, see Harrison et al. (2010).

MI provides an indirect bioclimatic measure of annual plant water availability, which might be expected to capture the distribution of peatlands better than mean annual precipitation because the latter neglects the large differences in evaporative demand between climates at different latitudes and with differing degrees of cloudiness. The lower bound of MI is zero; there is no theoretical upper bound, but values in the range of 3 to 6 are encountered in the wettest regions. Sykes et al. (1996) expressed the water requirements of tree species in STASH in terms of the now widely used index $\alpha$, which is an estimate of the ratio of actual evapotranspiration (AET) to EET (Harrison et al. 2010). AET is computed using the simple soil-moisture accounting scheme of Prentice et al. (1993), who provided literature sources for all of the equations and parameters listed below. In the accounting scheme, daily soil moisture $\left(\Omega_{i}\right)$ is calculated as the minimum of 2 functions:

$$
\Omega_{i}=\min \left\{\left[\Omega_{i-1}+\left(P_{i}-\mathrm{AET}_{i}\right)\right], \Omega_{\max }\right\}
$$

where $P_{i}$ is daily (interpolated) precipitation $(\mathrm{mm}), i$ is the day of the year, $\Omega_{\max }$ is the soil water-holding capacity (mm), and AET is calculated as the minimum of supply $(S)$ and demand $(D)$ functions:

$$
\begin{gathered}
\mathrm{AET}=\min \{S, D\} \\
S=C_{\mathrm{w}}\left(\Omega_{i-1} / \Omega_{\max }\right)
\end{gathered}
$$

where $C_{\mathrm{w}}\left(1 \mathrm{~mm} \mathrm{~h}^{-1}\right)$ is the maximum evapotranspiration rate from wet soils under conditions of high demand. The demand function $D$ is equated with the equilibrium evapotranspiration:

$$
D=\mathrm{EET}
$$

determined from the energy supply for evaporation:

$$
\mathrm{EET}=3600[s /(s+\gamma)] R_{\mathrm{n}} / L
$$

where $R_{\mathrm{n}}$ is net radiation $\left(\mathrm{W} \mathrm{m} \mathrm{m}^{-2}\right.$ ) and $s$ is the rate of increase of saturated vapour pressure with temperature $\left(\mathrm{Pa} \mathrm{K}{ }^{-1}\right)$, given by:

$S=2.503 \times 10^{6} \times \exp [17.269 T /(273.3+T)] /(273.3+T)^{2}$

where $T$ is the daily (interpolated) temperature in ${ }^{\circ} \mathrm{C}$, $\gamma$ is the psychrometer constant (ca. $65 \mathrm{~Pa} \mathrm{~K}^{-1}$ ) (SimõesMoreira 1999) and $L$ is the latent heat of vaporization of water $\left(2.5 \times 10^{6} \mathrm{~J} \mathrm{~kg}^{-1}\right)$ (Lide \& Frederikse 2001).

The instantaneous net radiation $\left(R_{\mathrm{n}}\right)$ is calculated as the difference between net downward shortwave flux $\left(R_{\mathrm{s}}\right)$ and net upward longwave flux $\left(R_{\mathrm{l}}\right)$ :

$$
R_{s}=\left(c+d n_{i}\right)(1-\beta) Q_{0} \cos z
$$

where $c$ and $d$ are empirical constants $(c=0.25, d=0.50$; $c+d=$ clear-sky transmissivity), $n_{i}$ is the daily (interpolated) fraction of sunshine hours, $\beta$ is the shortwave albedo (assumed constant at 0.17 for this calculation) and $z$ is the sun angle. $Q_{0}$, the insolation on a horizontal surface at the top of the atmosphere, is calculated as:

$$
Q_{\mathrm{o}}=Q_{\mathrm{oo}}[1+2 \times 0.01675 \times \cos (360 i / 365)]
$$

where $Q_{\mathrm{oo}}$ is the solar constant $\left(1360 \mathrm{~W} \mathrm{~m}^{-2}\right.$ ) (Willson \& Mordvinov 2003) and:

$$
\cos z=\sin l \sin \delta \cos h
$$

where $l$ is latitude, $\delta$ is the solar declination:

$$
\delta=-23.4^{\circ} \cos [360(i+10) / 365]
$$

and $h$ is the time of day, in angular units from solar noon.

The net upward long-wave flux is approximated by:

$$
R_{l}=\left[b+(1-b) n_{i}\right](A-T)
$$

where $b$ and $A$ are empirical constants equal to 0.2 and $107^{\circ} \mathrm{C}$, respectively, and $T$ is the mean daily temperature in ${ }^{\circ} \mathrm{C}$.

Instantaneous $R_{\mathrm{n}}$ is integrated analytically over the daylight hours to yield daily $R_{\mathrm{n}}$, disregarding an effect of diurnal variations in temperature on $R_{\mathrm{n}}$. The index $\alpha$ is calculated by equating annual PET with the evaporative demand term $D$. Water in excess of the soil water-holding capacity is routed to runoff.

MI and $\alpha$ are conceptually and empirically related (e.g. Zhang et al. 2004). However, for modelling peatland distribution, the assumptions of the soil moisture accounting scheme (required for AET) might be a poor approximation for the particular hydrological properties of peat. Furthermore, we found empirically that limit values of MI fitted the distribution of blanket peatlands more accurately than limit values of $\alpha$. Accord- 
ingly, MI is used as the index of water availability in the present study. The calculation of MI depends on the algorithm used to calculate EET; it does not depend on AET, the supply function $S$ or the prescribed soil properties. It is known that $\alpha$ is insensitive, from a biological point of view, at the wet end of the scale (Harrison et al. 2010). This is probably due to the monthly rainfall being artificially distributed through all the days of the month, neither MI nor $\alpha$ account for the possibility of runs of dry days, even in relatively wet climates. In fact, $\mathrm{MI}$ is independent of the timing of precipitation events and of seasonality of rainfall. However, these limitations are not serious at the wet end of the scale, when the bioclimatic envelope of blanket peatlands is approached, because, in practice, these climates experience year-round precipitation. The advantage of using MI is that it continues to increase with increasing precipitation, when $\alpha$ has reached its maximum value.

\subsection{Data sets}

\subsubsection{Blanket peatland maps}

Global blanket peatland map. There are only very limited data available on the global distributions of mire complexes. The map used in the present study for the global calibration of PeatStash of blanket peatlands is the one compiled by Lindsay et al. (1988).

Blanket peatland map of Great Britain. A blanket peatland map was produced by combining the mapped area of blanket peatlands from the soil survey map for England and Wales (NATMAPvector, 1:250 000) and Scotland (National Soils Map, NSM, 1:250 000) (as described fully in Clark et al. 2010). In England and Wales, peat soils meet both of the following criteria: (1) either $>40 \mathrm{~cm}$ of organic material is found within the upper $80 \mathrm{~cm}$ of the soil profile, or $>30 \mathrm{~cm}$ of organic material rests directly on bedrock or skeletal material; and (2) no superficial non-humose mineral horizons with a colour value of 4 or more that extends below $30 \mathrm{~cm}$ depth (Clayden \& Hollis 1984). Blanket peatlands were mapped under 3 soil associations: Winter Hill (1011b), Crowdy 1 (1013a) and Crowdy 2 (1013b), belonging to the raw peat soils group (10.1) (Avery 1980). In Scotland, peat is classified as an organic deposit ( $>60 \%$ organic matter) with a depth greater than $50 \mathrm{~cm}$ (Chapman et al. 2009).

\subsubsection{Climate data}

Climate baseline data. Monthly $5 \mathrm{~km}$ gridded climate data from the Met Office were used (www. metoffice.gov.uk). The gridded data were produced by integrating long-term meteorological measurements using interpolation and multiple regression models based on location (easting and northing), terrain elevation, open water and urban land use (Perry \& Hollis 2005). Monthly data for precipitation (mm), cloud cover $(\%)$ and mean temperature $\left({ }^{\circ} \mathrm{C}\right)$ averaged over the 1961-1990 period were used. The potential for a poor representation of upland precipitation in the Met Office data due to fewer rain gauges at high elevations is not addressed.

Future climate projections: UKCIP02. Climate scenarios were obtained for the UK from the UK Climate Impacts Programme (UKCIP, www.ukcip.org.uk) (Hulme et al. 2002). These scenarios were derived from the Hadley Centre Global Climate Model (HadCM3) output for 4 global emissions profiles, developed by the IPCC Special Report on Emissions Scenarios (IPCC 2000): A1FI (high emissions), A2 (medium-high emissions), B2 (medium-low emissions) and B1 (low emissions); only A1F1 and B1 are used in the present study. Changes in monthly mean climate values were available at a $50 \mathrm{~km}$ scale for 3 different periods: 20112040, 2041-2070 and 2071-2100, hereafter referred to as the 2020s, 2050s and 2080s, respectively. The projected change in climate variables at the $50 \mathrm{~km}$ scale was applied to the observed 1961-1990 $5 \mathrm{~km}$ baseline data. Projected changes used were for monthly change in mean temperature $\left({ }^{\circ} \mathrm{C}\right)$, total precipitation $(\%)$ and cloud cover (\%).

Future climate projections: GCMs. Future climate projections derived from a suite of 7 different climate models were also used to capture some of the uncertainty due to the choice of GCM. These runs were carried out as part of the QUEST GSI project (Quantifying and Understanding the Earth SysTem-GlobalScale Impacts of climate change; www.cru.uea.ac.uk/ rimo/climgen/data/questgsi/) using ClimGen, which is a tool developed by Mitchell \& Osborn (2005) to generate fields of climate data using a 'pattern scaling' approach (Mitchell et al. 2004), whereby patterns of change simulated by a suite of GCMs for a prescribed scenario of $+2^{\circ} \mathrm{C}$ warming by 2050 were applied to an observed $0.5^{\circ} \times 0.5^{\circ}$ gridded baseline climatology (New et al. 2000). The suite of 7 models included (1) CGCM3, the third generation Canadian coupled GCM from the Canadian Centre for Climate Modelling and Analysis (CCCMA); (2) the Australian GCM from the Commonwealth Scientific and Industrial Research Organisation (CSIRO); (3) the new IPSL climate system model (IPSLCM4) from the Institute Pierre Simon Laplace (France); (4) ECHAM GCM5, a comprehensive general circulation model of the atmosphere from the Max Plank Institute (Germany); (5) the community climate system model (CCSM) version 3.0 from the US National Centre for Atmospheric Research (NCAR); 
(6) the Hadley Centre Coupled Model, version 3 (HadCM3), a coupled atmosphere-ocean general circulation model (AOGCM) from the Hadley Centre; and (7) the coupled Hadley Centre Global Environmental Model, version 1 (HadGEM1).

\subsection{Model calibration}

The threshold values used in PeatStash were: an MI above 2.1 , a mean annual temperature above $-1.0^{\circ} \mathrm{C}$ and a mean temperature of the warmest month not to exceed $14.5^{\circ} \mathrm{C}$. These are simply the values that best fitted the global distribution of blanket peatlands (A. V. GallegoSala, J. Clark, J. House, I. C. Prentice and others unpubl.). These same thresholds were used to predict the distribution of blanket peatlands in the UK. Thus, the model was calibrated at a global scale and directly applied to the UK without additional calibration.

\subsection{Data analysis}

\subsubsection{Model performance statistics}

Model sensitivity, accuracy and Kappa statistics (Cohen 1960) were calculated for all models based on the ability to predict presence/absence of present-day blanket peatlands. Sensitivity was defined as the total number of recorded presences correctly predicted, as a fraction of the total number of presences recorded in the data (Pearce \& Ferrier 2000). Accuracy was defined as the number of correctly identified presences and absences recorded in the whole data set (Pearce \& Ferrier 2000). The Kappa statistic measures the correct classification rate after the probability of chance agreement has been removed (Cohen 1960), which is often considered to be a better measure of predictive accuracy than sensitivity or accuracy. We also recorded the errors of omission, i.e. the number of grid cells where the model failed to predict peat where peat has been observed, and errors of commission, i.e. the number of grid cells where the model predicts peat but there is none.

\subsubsection{Sensitivity analysis independent of climate scenario}

Model sensitivity analysis was carried out with respect to each of the 3 input climate variables: temperature, precipitation and cloud cover. Factorial changes for cloud cover and difference changes for temperature and precipitation were applied, one at a time, to the monthly 1961-1990 baseline climate data. The percent- age change in the bioclimatic spatial distribution for the model was compared relative to the results obtained using the 1961-1990 baseline climate data.

2.4.3. Scenario-dependent sensitivity analysis: drivers of change

An additional sensitivity test was performed on PeatStash to assess which climate variable(s) drive the predicted changes in blanket peatland extent for the different scenarios. These tests use the UKCIP02 climate data sets based on 2 different IPCC SRES emissions scenarios (A1F1 and B) for 3 different periods: the 2020s, 2050s and 2080s. The projected changes in climate are not always just a constant increase or decrease in mean monthly variables, but usually include a change in seasonality. For example, rain patterns are likely to change differently during the winter and summer months, and UKCIP02 predicts drier summers and wetter winters (Hulme et al. 2002). For this reason, we use the projections for each variable (rain, temperature and sunshine fraction), while keeping the rest of the variables constant at the baseline value. This further sensitivity test is used to examine the cause of the predicted changes in the area within the bioclimatic envelope under future climate scenarios.

\section{RESULTS}

\subsection{Model calibration}

The threshold values used in PeatStash were those that best fitted the global distribution of blanket peatlands (Table 1); these limit values were directly applied to Great Britain without additional calibration (Fig. 1).

\subsection{Model fit to present-day blanket peatland distribution}

PeatStash performed well and was able to correctly predict blanket peatland presence and absence compared to the present-day blanket peatland distribution map, with high values of sensitivity, accuracy and Kappa statistic (Table 2). According to the Kappa statistic, PeatStash performed within the upper limit of the interval 0.6 to 0.8 , which is considered to be a substantial agreement beyond chance (Landis \& Koch 1977). There were more errors of commission than omission, i.e. PeatStash tends to slightly overestimate the total extent of blanket peatlands (Fig. 1). 
Table 1. Chosen thresholds for the global distribution of blanket peatlands for 3 bioclimatic variables: moisture index (MI, unitless), mean annual temperature $\left(T_{\text {mean }}\right)$ and mean temperature of the warmest month $\left(T_{\text {warm }}\right)$. n/a: not applicable, only a minimum or maximum threshold were set for these variables

\begin{tabular}{|lccc|}
\hline Threshold & MI & $T_{\text {mean }}\left({ }^{\circ} \mathrm{C}\right)$ & $T_{\text {warm }}\left({ }^{\circ} \mathrm{C}\right)$ \\
\hline Upper & n/a & n/a & 14.5 \\
Lower & 2.1 & -1.0 & n/a \\
\hline
\end{tabular}

\subsection{Sensitivity analysis independent of climate scenario}

The results of the sensitivity analysis indicate that the modelled peat area decreases with increased temperature, decreased precipitation and decreased cloud cover (increased sun fraction) (Fig. 2). The slope of each curve in Fig. 2 is an indication of the sensitivity of the bioclimatic envelope to the change in the variable. The modelled area is very sensitive to increases in temperature (especially the interval 0 to $+2^{\circ} \mathrm{C}$ ), i.e. a relatively small change in temperature results in a large change in bioclimatic envelope extent. The curve tails off as the blanket peatland envelope disappears. The envelope is more sensitive to decreases than to increases in precipitation, probably because, in the model, the bioclimatic envelope cannot extend to grid cells where the maximum mean monthly temperature is above a given threshold $\left(+14.5^{\circ} \mathrm{C}\right)$. There are therefore areas that could not be covered in blanket peatlands, even if precipitation were to increase substantially. The model is less sensitive to potential changes in cloud cover than to the other 2 variables.

\subsection{Projected future changes in blanket peatland bioclimatic area}

The general response to the predicted changes in climate for the UKCIP02 high and low emissions scenarios is a retreat in the peat bioclimatic area to the north and west of Great Britain (Fig. 3). In the high emissions scenario, for the 2080s period, there is a loss of $\sim 84 \%$ of the present-day peatland bioclimatic area, whereas, even for the low emissions scenario during the same period, the decline represents more than half of the present area (Table 3).

The same pattern of retreat towards the west and north of Great Britain was observed when PeatStash was run using climate projections from 7 climate models (Fig. 4). All simulations agree on the loss of blanket peatland bioclimatic space in England, Wales and the east of Scotland. The climate projected by

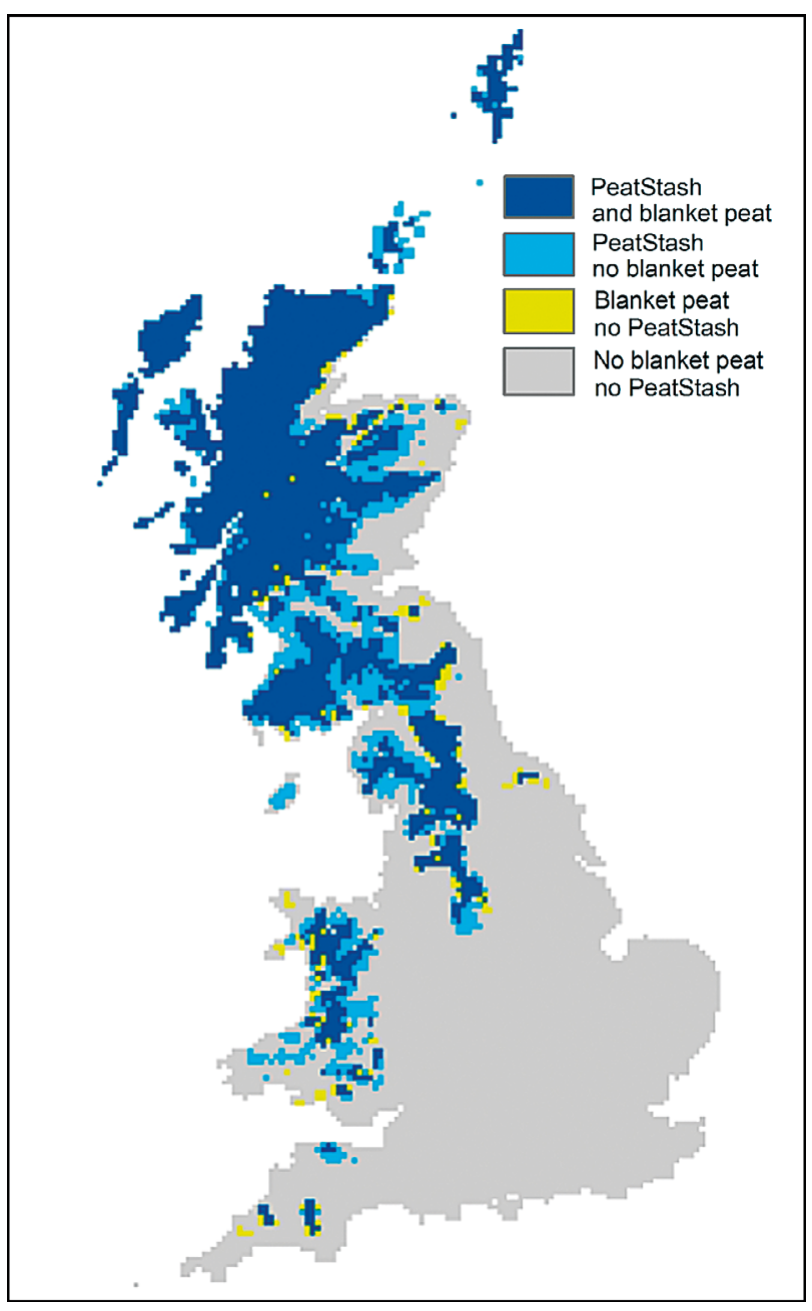

Fig. 1. Overlay of of the PeatStash predicted area of blanket peatland bioclimatic envelope for the baseline climate period (1961-1990) on the mapped $5 \mathrm{~km}$ gridded data of blanket peatland presence. An Ordnance Survey/EDINA supplied service (@ Crown Copyright/database 2009) and Met Office/ UKCIP gridded climate data (UKCIP02 @ Crown Copyright 2002)

IPSLCM4 leads to the greatest shrinkage of the area incorporated within the blanket peatland envelope, such that no areas of Great Britain have a climate that matches this bioclimatic space. Climates projected by

Table 2. Model fit and accuracy, comparing the output of PeatStash for the baseline climate data with the observed blanket peatland map. Sens.: sensitivity; Acc.: accuracy; Kappa: Kappa statistic; Omiss.: errors of omission; Commiss.: errors of commission; Grid cells: total no. of grid cells

\begin{tabular}{|lcccccc|}
\hline Test & $\begin{array}{c}\text { Sens. } \\
(\%)\end{array}$ & $\begin{array}{c}\text { Acc. } \\
(\%)\end{array}$ & Kappa & Omiss. & Commiss. & $\begin{array}{r}\text { Grid } \\
\text { cells }\end{array}$ \\
\hline PeatStash & 88.7 & 89.7 & 0.77 & 192 & 843 & 9757 \\
\hline
\end{tabular}



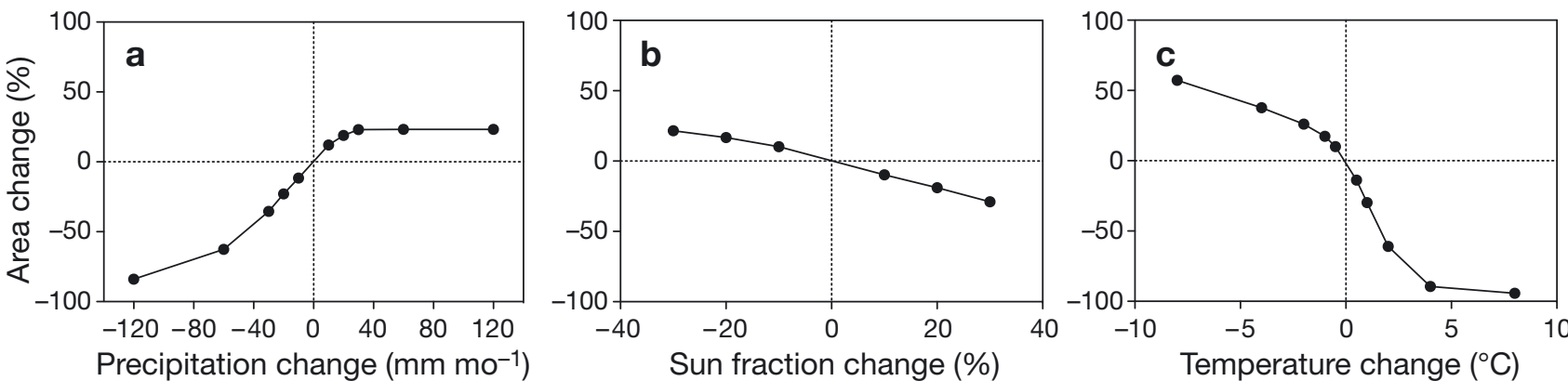

Fig. 2. Sensitivity analysis of PeatStash independent of climate scenario: percentage change in the area covered by blanket peatland bioclimatic space for a constant change in: (a) mean monthly precipitation, (b) mean monthly sun fraction and (c) mean monthly temperature for the 1961-1990 baseline climate data

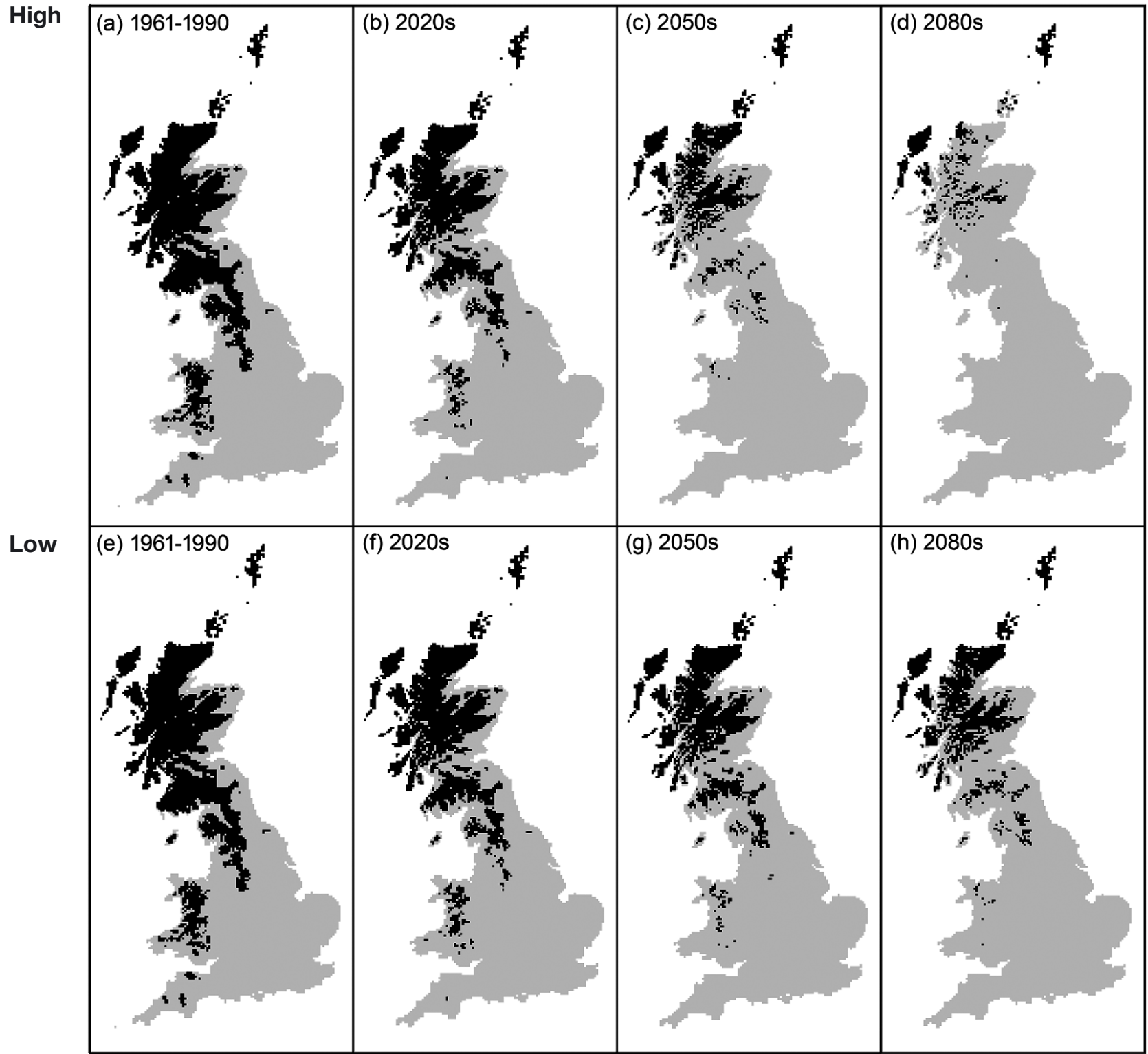

Fig. 3. Area covered by the bioclimatic envelope of blanket peatlands predicted by PeatStash using the bioclimatic thresholds associated with the 1961-1990 baseline climate for the UKCIP02 high and low emissions scenarios ('High' and 'Low', respectively) for 3 time periods: 2020s, 2050s and 2080s. An Ordnance Survey/EDINA supplied service (@ Crown Copyright/database 2009) and Met Office/UKCIP gridded climate data (UKCIP02 @ Crown Copyright 2002) 
Table 3. Percentage decrease of areal extent of the blanket peatland bioclimatic envelope compared with its present-day distribution for 3 time periods: 2020s, 2050s and 2080s; and 2 UKCIP02 emissions scenarios: high and low

\begin{tabular}{|lccc|}
\hline Emmissions scenario & $2020 \mathrm{~s}$ & $2050 \mathrm{~s}$ & $2080 \mathrm{~s}$ \\
\hline High & 32 & 60 & 84 \\
Low & 28 & 43 & 53 \\
\hline
\end{tabular}

ECHAM GCM5 and CCCMA CGCM3 models result in the least shrinkage. When PeatStash is run using the climate space predicted by the CSIRO and NCAR CCSM3 models, the resulting geographical distribution of the peat bioclimatic envelope is similar to that obtained using the 2 Hadley Centre model predictions HadCM3 and HadGEM1, and falls somewhere between the 2 extremes. Because HadCM3 is the GCM model output underlying the downscaled UKCIP02 projections, this implies that the projected change in blanket peatland climate space shown by UKCIP02 (Fig. 3) is somewhere in the middle ground of GCM projections.
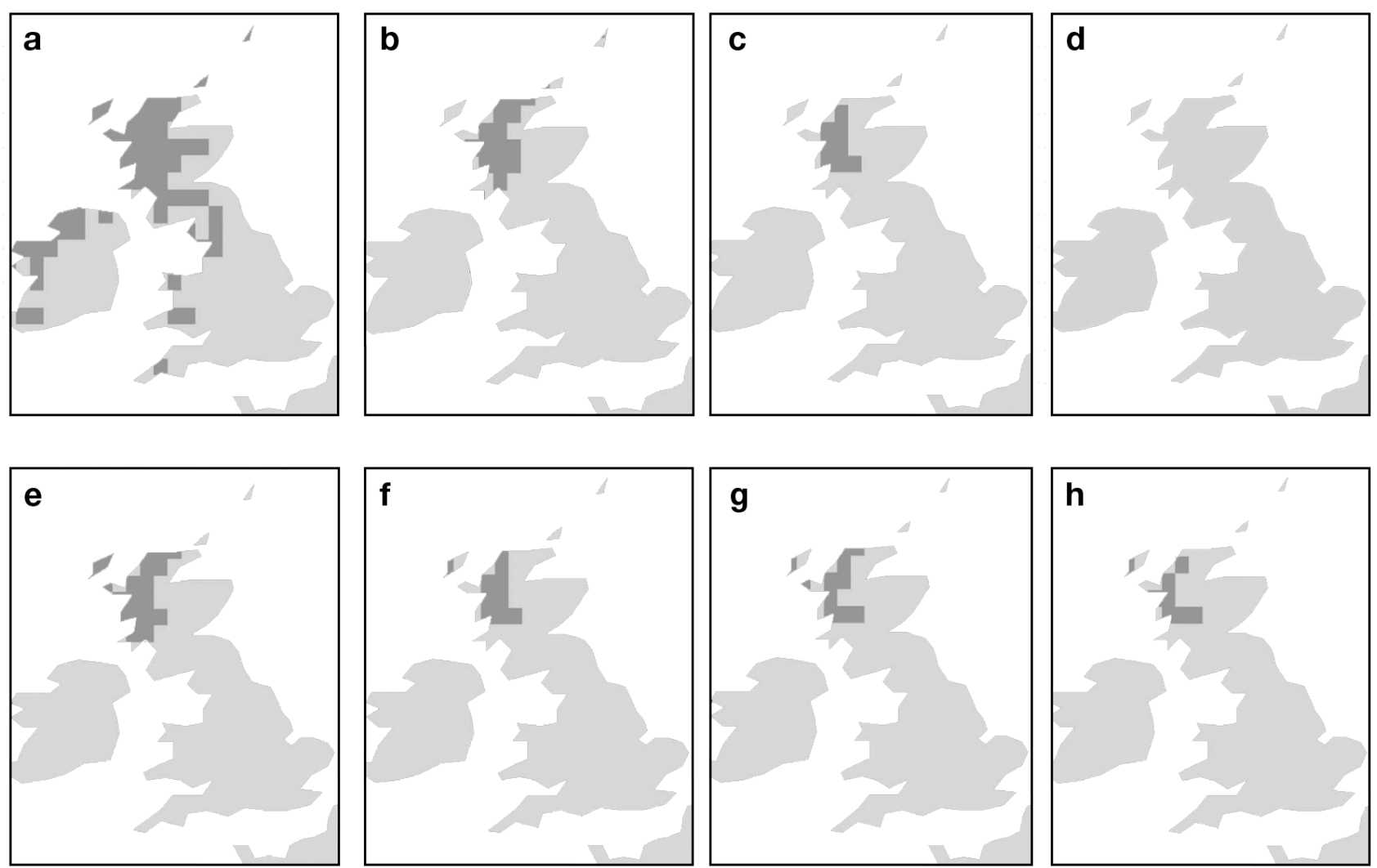

Fig. 4. Changes in the extent of the blanket peat bioclimatic envelope area compared with (a) present-day climate, as predicted by PeatStash using 7 different GCM predictive outputs for 2070-2099 at 0.5 resolution: (b) CCCMA CGCM3, (c) CSIRO, (d) IPSLCM4, (e) ECHAM GCM5, (f) NCAR CCSM 3.0, (g) HadCM3 and (h) HadGEM1. Climate projections are based on a scenario of $2.0^{\circ} \mathrm{C}$ warming by 2050 . Dark grey areas are within the blanket peatland bioclimatic envelope and light grey areas are those outside 

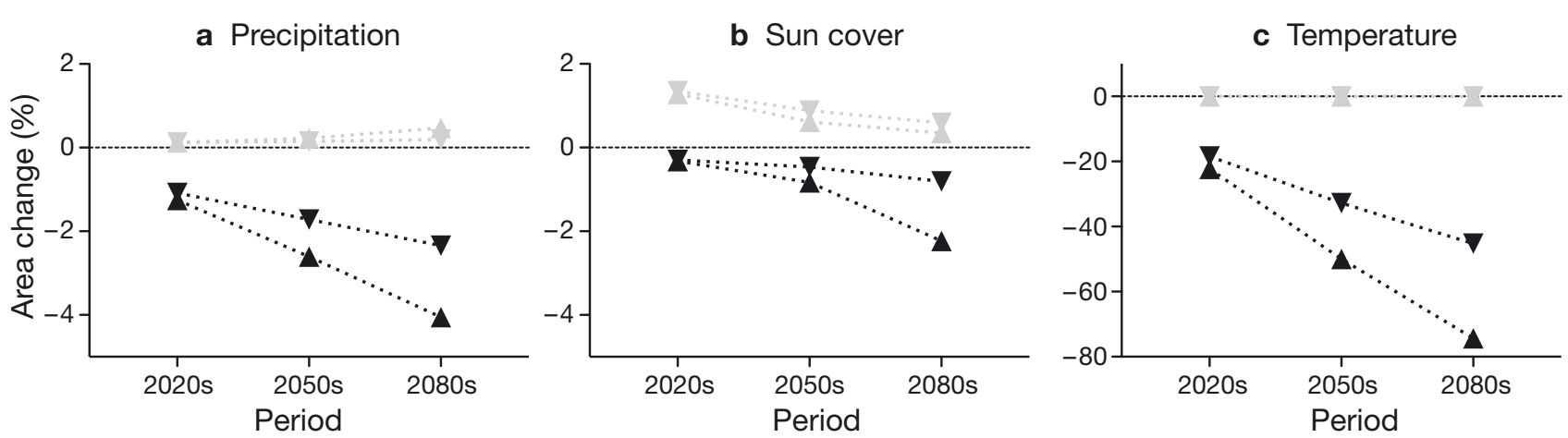

Fig. 5. Scenario-dependent sensitivity analysis of PeatStash. Percentage decrease (black triangles) and increase (grey triangles) in the area covered by the blanket peatland bioclimatic space due to the predicted changes of the climatic variables (a) precipitation, (b) sun cover and (c) temperature under UKCIP02 high (upwards-pointing triangles) and low (downwards-pointing triangles) emissions scenarios for 3 time periods: the 2020s, the 2050s and the 2080s. Note the change of scale in panel c

cover alone. But at the same time, predicted changes in cloud cover decrease MI in the high-elevation areas where most blanket peatlands are located. Projected changes in precipitation patterns slightly increase MI values in the eastern and western coasts of Scotland, but decrease MI elsewhere.

Projected changes in the bioclimatic space for blanket peatand growth are the result of the combined effect of these variables, and the combined effect is overwhelmingly to reduce the area within bioclimatic space for blanket peatlands. In general, the projected future climates are warmer and drier in summer than present-day climates, causing a reduction in the geographical extent of the blanket peatland bioclimatic envelope because of both the direct effect of warmer summers, and the indirect effects of increased PET and reduced precipitation on $\mathrm{MI}$.

\section{DISCUSSION}

\subsection{Model performance and sensitivity}

Blanket mires are more directly controlled by climate than some other types of peatland because of their reliance on precipitation alone to replenish soil moisture and maintain a high water table level. To a certain extent, this may explain why the predicted distribution of blanket peatlands from the model matches the observed distribution so closely. These ecosystems are very sensitive even to decadal variability in climate (Ellis \& Tallis 2000). It is therefore likely that the present distribution of blanket peatlands in Great Britain is close to equilibrium with the current climate, notwithstanding anthropogenic disturbances such as drainage and other land-use changes.

Our model is remarkably transparent and parsimonious, depending on just 3 bioclimatic limits (MI, mean annual temperature and mean temperature of the warmest month), acting independently, to accurately describe the distribution of blanket peatlands. Despite being calibrated on a global data set, PeatStash compares well to statistical models that were calibrated on Great Britain data sets; its performance measures are close to those of the best-fit statistical bioclimatic models presented in Clark et al. (2010).

The geographic distribution of the blanket peatland bioclimatic envelope, as predicted by PeatStash, is very sensitive to increases in temperature and, to a lesser degree, decreases in precipitation. Parviainen \& Luoto (2007) also reported that both precipitation and temperature were the main explanatory variables for the occurrence of blanket peatlands, unlike the occurrences of every other type of mire in Fennoscandia, which were explained by temperature alone.

\subsection{The future of blanket peatlands in Great Britain}

All PeatStash simulations run using climate input from the UKCIP02 high and low emissions scenarios and from 7 different GCM projections predict a retreat of the area covered by the blanket peatland bioclimatic envelope compared to the present distribution of peatlands. The general pattern of change is a gradual shift towards the north and west. Our application of a globally calibrated process-based bioclimatic envelope model is consistent with findings from statistical bioclimatic envelope models specifically calibrated for Great Britain (Clark et al. 2010). To account for the uncertainty in using what are, in essence, the predictions of a single GCM, i.e. the Hadley Centre model, PeatStash was additionally run at a lower resolution using a suite of 7 different GCMs. All 7 simulations run with climate projections based on a scenario of $2.0^{\circ} \mathrm{C}$ warming by 2050 predict the disappearance or shrinkage of the areas inside the blanket peatland bioclimatic envelope in England and Wales, and eastern parts of Scotland. 
Our study is consistent with previous model-based studies, which have suggested that peatlands in Canada may 'migrate' northwards as a result of elevated temperatures and drought (Gignac et al. 1998). Some field studies also suggest that peatland ecosystems at lower latitudes may not be well adapted to survive the more frequent extreme heat waves predicted in Europe and North America as part of global warming (Meehl \& Tebaldi 2004, Bragazza 2008).

The temperature changes projected by UKCIP02 are the most important driver in the change of geographical distribution of the peat bioclimatic envelope predicted by PeatStash. The importance of temperature as a factor controlling the destabilization of peatlands has been pointed out in other studies (Freeman et al. 2001, Ise et al. 2008). Paludification is the accumulation of soil organic carbon and the resulting water table rise due to the high water holding capacity of peat and its low hydraulic conductivity, which results in anoxia and further slowing down of the decomposition processes in the soil and consequent peat growth. This feedback between water table and peat depth has been suggested to increase the sensitivity of peat decomposition to temperature and to accelerate carbon loss whenever the climate is unfavourable to peat accumulation (Ise et al. 2008).

By contrast, future changes in cloudiness and precipitation are less well defined in climatic projections, and global water availability projections remain uncertain (Kingston et al. 2009). The increase in the North Atlantic Oscillation index and related increase in precipitation over western Europe may, in part, compensate for the possible increase in temperature (Moore 2002). However, changes in the distribution of rainfall, with wetter winters and drier summers (Jenkins et al. 2009), may exacerbate the impact of increased temperatures and increase the water deficit in British peatlands during summer months.

Being outside the blanket peatland bioclimatic envelope would not necessarily imply a sudden and complete loss of the peatland habitat or its carbon storage capabilities, especially if the sphagnum cover is maintained (Woike \& Schmatzler 1980), because of peat resilience once established. A more complex processbased coupled physical-biogeochemical soil model was used to examine climate impact in Canadian peatlands (Ise et al. 2008). Both shallow and deep peat soils were subjected to an instantaneous $4^{\circ} \mathrm{C}$ increase in temperature and the soil organic carbon (SOC) was modelled over a period of 2000 yr. The results from this model suggest that shallow peat layers will lose $40 \%$ of their SOC within 700 yr. Deep peat layers were shown to exhibit some resilience to SOC loss over the first $200 \mathrm{yr}$, but in the longer term (from 300 to $600 \mathrm{yr}$ ), $86 \%$ losses in SOC were predicted. At the fastest rate of decline, this is a loss of SOC of $\sim 0.3 \% \mathrm{yr}^{-1}$.
Climate change is not the only factor driving carbon losses from soil. Between 1978 and 2003, the mean temperature across England and Wales increased by approximately $0.5^{\circ} \mathrm{C}$ (Hulme et al. 2002). The measured actual loss of carbon from topsoils in England and Wales during this period (NSRI 2010) has shown a rate of SOC loss, in the region of $0.6 \% \mathrm{yr}^{-1}$ on average and up to $2 \%$ $\mathrm{yr}^{-1}$ in organic soils (Bellamy et al. 2005). Smith et al. (2007) and Kirk \& Bellamy (2010) suggest that only at most $10 \%$ of the carbon losses observed in Bellamy et al. (2005) could be attributed to climate change and that the majority of the loss is a consequence of land-use change. This would lower the rate of SOC loss due to climate change to a level comparable with that reported by Ise et al. (2008). A review of the current state of UK peatlands (Billett et al. 2010, this Special) suggests that the present carbon accumulation rates of a number of blanket peatlands may have slowed down compared with the last century. It is important to highlight that peatlands are flexible ecosystems, able to respond to and survive change, and their exact response to climate change remains ambiguous (Lindsay 2009). A rate of carbon loss or possible resilience of peat to a changing climate is beyond the scope of the present study.

There have been suggestions that the oceanic mires of Great Britain might not be under the same threat from climate change as other more continental mires; for example, it has even been proposed that northern oceanic peatlands are increasing in area, due to a retreat of the tree line and an ecological succession towards bogs where there were previously forests (Crawford et al. 2003). Our results do not provide support for this view.

The future distributions of the blanket peatland bioclimatic envelope under different emissions scenarios imply that blanket peatlands in England and eastern Scotland in particular will be under stress from changes in climate. The eventual fate of these ecosystems remains uncertain. Peatlands falling outside the bioclimatic envelope in the future might not disappear completely or swiftly, but will not be actively growing and, therefore, are unlikely to continue acting as carbon sinks.

\subsection{Model limitations}

There is continuing debate on the limitations and usefulness of bioclimatic envelope models (Pearson \& Dawson 2003, Hampe 2004, Thomas et al. 2004, Thuiller et al. 2004, Heikkinen et al. 2006). One criticism of these models is that they do not take into account biotic interactions, such as predation, competition or mutualism, when these are key mechanisms determining the distribution of species (Hampe 2004), but these interactions are not relevant for assessing habitat suitability. Further, these processes may be more im- 
portant at finer scales (Pearson \& Dawson 2003) and in situations where the predicted change to the present distribution is an expansion rather than shrinkage.

Another criticism of this type of model is the disregard of adaptive genetic variations (Woodward \& Beerling 1997). Peatland ecosystems may be robust, to a certain extent, to changes in the environment, and they have been capable of adapting to past environmental or climatic changes (Lindsay 2009). However, blanket peatlands are special ecosystems in that they are ombrotrophic mires dependent on high water table levels, which are maintained solely by the right climatic conditions, i.e. high precipitation and low temperature, and as such, they are highly vulnerable to climate change (Gignac et al. 1998, Ellis \& Tallis 2000).

A drawback of the MI employed in PeatStash is that it is calculated using mean annual variables and therefore may not pick up extreme weather events, or seasonal variation, e.g. drought periods in the summer months.

\section{CONCLUSIONS}

PeatStash correctly predicts the current geographical distribution of blanket peatlands in Great Britain using just 3 bioclimatic variables: MI, temperature of the warmest month and mean annual temperature. Simulations run using future UKCIP02 climate projections suggest the retreat of the areal extent of the blanket peatland bioclimatic envelope towards the north and west of Great Britain. Peatland areas that become excluded from the bioclimatic envelope are likely to experience changes in hydrology and vegetation and to cease active growth. However, the detailed fate of these threatened blanket peatland ecosystems is unknown and depends not only on pressures stemming from climate change, but on management practices and policy. Our results aim to provide information on one key factor - the potential effect of climate change on the extent of blanket bogs that may influence decisions concerning the conservation and restoration of British peatlands.

Acknowledgements. We are grateful to the Environment Agency (Science project sc070036) and the Natural and Environmental Research Council (NERC), through the Quantifying and Understanding the Earth System (QUEST) research programme, for funding this project. P.S. is a Royal SocietyWolfson Research Merit Award holder. The views expressed are those of the authors and do not necessarily reflect those of the funding bodies. We also thank M. Sykes at Lund University for providing the STASH code, and F. Bragg at the University of Bristol for her assistance with accessing GCM data sets. We acknowledge the Met Office for the use of their gridded climate data; the UK Climate Impact Programme for providing future climate projections; and contributions made by the wider EA-QUEST Uplands project network (which includes over 50 researchers and policy makers) during workshops and other discussions.

\section{LITERATURE CITED}

Avery BW (1980) Soil classification for England and Wales (higher categories). Technical monograph No. 14. Rothamstead Experimental Station, Harpenden

Barkham JP (1993) For peat's sake: conservation or exploitation? Biodivers Conserv 2:556-566

Bellamy PH, Loveland PJ, Bradley RI, Lark RM, Kirk GJD (2005) Carbon losses from all soils across England and Wales 1978-2003. Nature 437:245-248

> Berry PM, Dawson TP, Harrison PA, Pearson RG (2002) Modelling potential impacts of climate change on the bioclimatic envelope of species in Britain and Ireland. Glob Ecol Biogeogr 11:453-462

- Billett MF, Charman D, Clark JM, Evans CD and others (2010) Carbon balance of UK peatlands: current state of knowledge and future research challenges. Clim Res 45:13-29

BRIG (Biodiversity Reporting and Information Group) (2008) UK biodiversity action plan; priority habitat descriptions. Maddock A (ed) UK Biodiversity Partnership. Available at www. ukbap.org.uk/library/UKBAPPriorityHabitatDescriptions finalAllhabitats20081022.pdf

Bonn A, Allott T, Hubacek K, Stewart J (2009) Drivers of environmental change in uplands. Routledge, Abingdon

Bragazza L (2008) A climatic threshold triggers the die-off of peat mosses during an extreme heat wave. Glob Change Biol 14:2688-2695

> Bragg OM, Tallis JH (2001) The sensitivity of peat-covered upland landscapes. Catena 42:345-360

Chapman SJ, Bell J, Donnelly D, Lilly A (2009) Carbon stocks in Scottish peatlands. Soil Use Manag 25:105-112

Clark JM, Gallego-Sala AV, Allott TEH, Chapman SJ and others (2010) Assessing the vulnerability of blanket peat to climate change using an ensemble of statistical bioclimatic envelope models. Clim Res 45:131-150

Clayden B, Hollis JM (1984) Criteria for differentiating soil series. Rothhamsted Experimental Station, Harpenden

Cohen J (1960) A coefficient of agreement for nominal scales. Educ Psychol Meas 20:37-46

Cornell S (2010) Valuing ecosystem benefits in a dynamic world. Clim Res 45:261-272

Crawford RMM, Jeffree CE, Rees WG (2003) Paludification and forest retreat in northern oceanic environments. Ann Bot 91:213-226

Davies GM, Gray A, Hamilton A, Legg CJ (2008) The future of fire management in the British uplands. Int J Biodivers Sci Manag 4:127-147

> Davis AJ, Jenkinson LS, Lawton JH, Shorrocks B, Wood S (1998) Making mistakes when predicting shifts in species range in response to global warming. Nature 391:783-786

> Dawson TP, Berry PM, Kampa E (2003) Climate change impacts on freshwater wetland habitats. J Nat Conserv 11: $25-30$

> Ellis CJ, Tallis JH (2000) Climatic control of blanket mire development at Kentra Moss, north-west Scotland. J Ecol 88:869-889

Freeman C, Evans CD, Monteith DT, Reynolds B, Fenner N (2001) Export of organic carbon from peat soils. Nature 412:785

Gignac LD, Nicholson BJ, Bayley SE (1998) The utilization of bryophytes in bioclimatic modeling: predicted northward migration of peatlands in the Mackenzie River Basin, Canada, as a result of global warming. Bryologist 101:572-587

Gignac LD, Halsey LA, Vitt DH (2000) A bioclimatic model for the distribution of sphagnum-dominated peatlands in North America under present climatic conditions. J Biogeogr 27:1139-1151

Hampe A (2004) Bioclimate envelope models: what they de- 
tect and what they hide. Glob Ecol Biogeogr 13:469-471 Harrison SP, Prentice IC, Barboni D, Kohfeld KE, Ni J, Sutra JP (2010) Ecophysiological and bioclimatic foundations for a global plant functional classification. J Veg Sci 21: 300-317

Heikkinen RK, Luoto M, Araujo MB, Virkkala R, Thuiller W, Sykes MT (2006) Methods and uncertainties in bioclimatic envelope modelling under climate change. Prog Phys Geogr 30:751-777

Hulme M, Jenkins GL, Lu X, Turnpenny JR and others (2002) Climate change scenarios for the United Kingdom: the UKCIP02 scientific report. Tyndall Centre for Climate Change Research, School of Environmental Sciences, University of East Anglia, Norwich

Huntley B, Green RE, Collingham YC, Willis SG (2007) A climatic atlas of European breeding birds. Lynx Edicions, Barcelona

IPCC (2000) Special report on emissions scenarios (SRES) Cambridge University Press, Cambridge

Ise T, Dunn AL, Wofsy SC, Moorcroft PR (2008) High sensitivity of peat decomposition to climate change through water-table feedback. Nat Geosci 1:763-766

Jenkins GJ, Murphy JM, Sexton DS, Lowe JA, Jones P, Kilsby CG (2009) UK climate projections: briefing report. Met Office Hadley Centre, Exeter

Kingston DG, Todd MC, Taylor RG, Thompson JR, Arnell NW (2009) Uncertainty in the estimation of potential evapotranspiration under climate change. Geophys Res Lett 36:L20403 doi:10.1029/2009GL040267

Kirk GJD, Bellamy PH (2010) Analysis of changes in organic carbon in mineral soils across England and Wales using a simple single-pool model. Eur J Soil Sci 61:406-411

Landis JR, Koch GG (1977) The measurement of observer agreement for categorical data. Biometrics 33:159-174

Lide DR, Frederikse HPR (eds) (2001) CRC handbook of chemistry and physics. CRC Press, Boca Raton, FL

Lindsay R (2009) Peatbogs and carbon: a critical synthesis. RSPB Scotland, Edinburgh

Lindsay RA, Charman DJ, Everingham F, O'Reilly RM, Palmer MA, Rowell TA, Stroud DA (1988) The flow country: the peatlands of Caithness and Sutherland. Nature Conservancy Council, Peterborough

Maltby E (2010) Effects of climate change on the societal benefits of UK upland peat ecosystems: applying the ecosystem approach. Clim Res 45:249-259

Meehl GA, Tebaldi C (2004) More intense, more frequent, and longer lasting heat waves in the 21st century. Science 305:994-997

Mitchell TD, Osborn TJ (2005) ClimGen: a flexible tool for generating monthly climate data sets and scenarios. Tyndall Centre for Climate Change Research, Norwich

Mitchell TD, Carter TR, Jones PD, Hulme M (2004) A comprehensive set of high-resolution grids of monthly climate for Europe and the globe: the observed record (1901-2000) and 16 scenarios (2001-2100). Tyndall Centre Working Paper 55, Tyndall Centre for Climate Change Research, Norwich

Moore PD (2002) The future of cool temperate bogs. Environ Conserv 29:3-20

Moore PD, Bellamy DJ (1973) Peatlands. Unwin Brothers, Surrey

New M, Hulme M, Jones P (2000) Representing twentiethcentury space and time climate variability. II. Development of 1901-96 monthly grids of terrestrial surface climate. J Clim 13:2217-2238

NSRI (2010) The national soil inventory. Cranfield University, Cranfield. Available at www.landis.org.uk
Parviainen M, Luoto M (2007) Climate envelopes of mire complex types in Fennoscandia. Geogr Ann Ser A 89: $137-151$

Pearce J, Ferrier S (2000) Evaluating the predictive performance of habitat models developed using logistic regression. Ecol Model 133:225-245

Pearce-Higgins JW, Murray CG, Beale CM, Buchanan GM, Sim IMW (2009) International importance and drivers of change of upland bird populations. In: Bonn A, Allott T, Hubacek K, Stewart J (eds) Drivers of environmental change in uplands. Routledge, London, p 209-227

Pearson RG, Dawson TP (2003) Predicting the impacts of climate change on the distribution of species: Are bioclimate envelope models useful? Glob Ecol Biogeogr 12: 361-371

Perry M, Hollis D (2005) The generation of monthly gridded datasets for a range of climatic variables over the UK. Int J Climatol 25:1041-1054

> Prentice IC, Sykes MT, Cramer W (1993) A simulation model for the transient effects of climate change on forest landscapes. Ecol Model 65:51-70

> Ramchunder SJ, Brown LE, Holden J (2009) Environmental effects of drainage, drain-blocking and prescribed vegetation burning in UK upland peatlands. Prog Phys Geogr 33: 49-79

Reed MS, Arblaster K, Bullock C, Burton RJF and others (2009) Using scenarios to explore UK upland futures. Futures 41:619-630

Simões-Moreira JR (1999) A thermodynamic formulation of the psychrometer constant. Meas Sci Technol 10:302

Smith P, Chapman SJ, Scott WA, Black HIJ and others (2007) Climate change cannot be entirely responsible for soil carbon loss observed in England and Wales, 1978-2003. Glob Change Biol 13:2605-2609

Sykes MT, Prentice IC, Cramer W (1996) A bioclimatic model for the potential distributions of north European tree species under present and future climates. J Biogeogr 23: 203-233

Thomas CD, Cameron A, Green RE, Bakkenes M and others (2004) Extinction risk from climate change. Nature 427: $145-148$

Thuiller W, Araujo MB, Pearson RG, Whittaker RJ, Brotons L, Lavorel S (2004) Biodiversity conservation: uncertainty in predictions of extinction risk. Nature 430 doi:10.1038/ nature 02716

Tuck G, Glendining MJ, Smith P, House JI, Wattenbach M (2006) The potential distribution of bioenergy crops in Europe under present and future climate. Biomass Bioenergy 30:183-197

United Nations Environment Programme (1992) World atlas of desertification. Edward Arnold, London

Wieder RK, Vitt DH (2006) Boreal peatland ecosystems. Spring-Verlag, Berlin

Willson RC, Mordvinov AV (2003) Secular total solar irradiance trend during solar cycles 21-23. Geophys Res Lett 30:1199 doi:10.1029/2002GL016038

Woike M, Schmatzler E (1980) Moore. Bedeutung - Schutz Regeneration. Deutscher Naturschutzring, Bonn

Woodward FI, Beerling DJ (1997) The dynamics of vegetation change: health warnings for equilibrium 'dodo' models. Global Ecol Biogeogr Lett 6:413-418

Zhang YC, Rossow WB, Lacis AA, Oinas V, Mishchenko MI (2004) Calculation of radiative fluxes from the surface to top of atmosphere based on ISCCP and other global data sets: refinements of the radiative transfer model and the input data. J Geophys Res 109:D19105 doi:10.1029/2003 JD004457 